\title{
Challenging Deficit Constructions of the International Student Category in Canadian Higher Education
}

Victoria Surtees

The trend toward internationalization on Canadian campuses has been simultaneously lauded as an opportunity for promoting campus diversity and criticized for creating a campus environment that is segregated along linguistic and ethnic lines. As a result of these tensions, students labelled as "international" have become the focus of increasing amounts of media attention. In this article, drawing on interviews with undergraduate students $(n=13)$ from one postsecondary Canadian institution, I examine how the seemingly neutral labels applied to diverse students, such as the category "international," operate in talk to reproduce deficit understandings of these students, particularly in regard to their English language abilities. I then provide evidence that students also construct more positive representations of international students through references to their experiences of migration and their expertise interacting with speakers of different Englishes. I offer the notion of "language brokers" as a helpful conceptual lens for interpreting this categorization and for reflecting on the contributions that international students make to Canadian higher education.

La tendance de l'internationalisation dans les universités canadiennes a simultanément été louée comme une occasion de promouvoir la diversité sur le campus et critiquée pour la ségrégation qu'elle opère dans l'environnement universitaire en fonction de l'appartenance linguistique et ethnique. Ces tensions ont pour effet d'attirer progressivement l'attention des médias sur les étudiants dits « internationaux ». Dans le présent article, je m'appuie sur des entrevues avec des étudiantes et étudiants de premier cycle $(n=13)$ inscrits dans un établissement postsecondaire canadien pour examiner la façon dont des étiquettes apparemment neutres accolées à des étudiants diversifiés, comme par exemple la catégorie des étudiants "internationaux », crée un langage qui reflète certains déficits de compréhension de tels étudiants, particulièrement en ce qui concerne leurs compétences linguistiques en anglais. J'apporte ensuite la preuve que les étudiants construisent également des représentations plus positives des étudiants internationaux à la lumière de leur expérience migratoire et de la compétence avec laquelle ils interagissent avec des interlocuteurs qui s'expriment dans les multiples variations de l'anglais. J'offre la notion de "courtier en langues » comme lentille conceptuelle utile pour l'interprétation de cette catégorisation et pour une réflexion sur les apports des étudiants internationaux à l'enseignement supérieur au Canada.

KEYWORDS: international students, representation, categories, diversity 


\section{Introduction}

In recent years, the number of international students enrolled in Canada's institutions of higher education has increased exponentially. According to Statistics Canada, in the 2016/2017 academic year, there were 245,895 international students attending Canada's postsecondary institutions. As of December 2018, that number had increased to 435,415 students, a rate of growth that significantly outpaced the increases in the domestic student population (Macdonald, 2019). This shifting demographic in higher education has made international student issues a key strategic focus in both policy and the broader media. On one hand, institutional and government policies tend to portray campus internationalization - and international students - as an opportunity for revenue generation and for enhancing campus diversity (e.g., Government of Canada, 2014). The Canadian media, on the other hand, have portrayed international students in a variety of ways, both positive and negative, by focusing primarily on their economic contributions, questioning the legitimacy of international students' credentials, and claiming that they may be displacing Canadian students in higher education (Anderson, 2019). Thus, international students are represented in broader societal discourses in a variety of ways, many of which reproduce deficit or dehumanizing understandings of who these students are and what they contribute to Canadian campuses.

In this article, I aim to engage critically with the issue of international student representation by examining how undergraduates talked about international students in research interviews. I do so with the understanding that, as Harklau (2000) states, categorical representations of students have consequences for students' motivations, engagement, and opportunities within schools and, thus, "it is important to account for the ubiquity of such categories and how they come to appear so stable, homogeneous, and takenfor-granted in a given context" (p. 37). First, I examine how students used the category "international" in talk to constitute students as certain kinds of people. Second, by examining the ways in which undergraduates talked about their international student peers in interviews, I foreground competing categorization practices in which international students are constructed as positive contributors to campus life.

Data are drawn from interviews with undergraduates $(n=13)$ attending a large Western Canadian university. The interviews were conducted as part of a multiple case study that explored how peer interaction supported study abroad students' English language learning (to learn more about these findings, see Surtees, 2018). Participants had varying institutional statuses (e.g., domestic student, international student), and most were multilingual. Following a review of the literature on representations of international students in policy and the media, I present findings that highlight how the category "international student" frequently served to index lower English language 
ability and racial otherness. I also highlight the ways in which participants constructed an alternative, more positive category of international student based on references to multilingualism and migration experience.

\section{Representations of International Students}

\section{International Students as Contributors to Campus Diversity}

Marshall (2002) defines diversity as "distinctions in the lived experiences, and the related perception of and reactions to those experiences that serve to differentiate collective populations from one another" (p. 7). There seems to be a reasonable consensus that internationalization - and by association international students - contribute to diversity on university campuses, and that diversity is not only desirable but also essential if students are to be adequately prepared for participation in an increasingly globalized society (Smith, 2015). The Federal government's policy on international education also alludes to the notion that diversity, which would primarily be achieved through international student recruitment, promotes an exchange of viewpoints, resources, and information. The document explains that international education creates jobs and revenue while also expanding "our people-to-people ties - ties proven to boost political, economic, social and developmental relationships"' (Government of Canada, 2014, p. 12). In a review of approaches to cultural diversity in Canadian higher education, Guo and Jamal (2007) also identify a number of benefits to the deliberate diversification of the student and staff populations at universities. These benefits include the "improvement in intergroup relations and campus climate, increased opportunities for accessing support and mentoring systems, opportunities for acquiring broader perspectives and viewpoints, and participating in complex discussions" (p. 30). Through these various discourses in policy and scholarship, international students are projected as both contributors to and beneficiaries of the opportunities that such a diverse landscape provides.

While this seems to be an overall positive vision of international students, Smith (2015) points out that the notion of diversity has proven notoriously vague in higher education, often resulting in diversity initiatives that struggle to recognize and support a long list of identities (e.g., linguistic, racial, cultural, religious, and gender). In some cases, these well-intentioned programs may also reproduce circulating stereotypes and position students who do not identify as White or as native-English speakers as resources for domestic students' learning (Trilokekar, 2016). These discourses, thus, portray international students as cultural commodities. As the next section will illustrate, the representation of international students primarily as a commodified asset is a thread that also runs through much of the policy and media coverage related to international students. 


\section{International Students as Commodities}

A number of studies have examined the ways in which the category, international student, is represented in policy and media in English-speaking countries (Anderson, 2019; Deschambault, 2015; Lin, 2019; Paltridge, Mayson, \& Schapper, 2014; Robertson, 2011). Each of these studies found that international students were disproportionately represented as commodities. For example, Deschambault (2015) examined the use of the category international student in policy documents from British Columbia's K-12 public school system. In his findings, he concluded that the category served to highlight the fees that could be obtained by recruiting students categorized this way, while other labels, such as "English Language Learner," were primarily resources for discussing additional government funding support. Similarly, Lin (2019) recently examined representations of K-12 international and Asian students in the Canadian media. She found articles and comments from Canadian news outlets discursively tied members of these categories to their potential for revenue generation in the wider community, where they might serve host families as "cash cows" (p. 86) or "mortgage helpers" (p. 115).

In his examination of 391 Canadian news media articles published between the years of 2000 and 2017, Anderson (2019) also found that the majority of articles represented international students as "dehumanized assets" (p. 15), valued for their economic contributions in the form of elevated tuition fees, consumption of local goods, and potential contributions to the labour market. He reports that although many of the articles presented an overall positive evaluation of internationalization and assigned value to the benefits that international students provided, the voices of international students were rarely present in these articles, leading to an overall impression of these students as commodities "instead of as individual people seeking better lives" (p. 21).

\section{International Students as Threats and Racialized Others}

In a subset of media publications, international students are also negatively constructed as racial others, victims, or foreigners (see, for example, Findlay \& Köhler, 2010; Quinn, 2012). These racialized constructions are often achieved through the unnecessary mention of categories related to race and country of origin alongside the use of the "international" label. For example, Paltridge, Mayson, and Schapper (2014) observed that in Australian newspaper articles about violent attacks against international students, the students were identified as "Indian," while the racial identities of the perpetrators went unmentioned.

Anderson (2019) also found that a significant number of articles, particularly those published in Vancouver, British Columbia, had thematic elements of what he terms "foreigner threat" (p. 19). In these articles, the news media authors draw on populist narratives in which Canadians are "being displaced 
and exploited by (linguistically and educationally) undeserving wealthy foreigners" (p. 19), often identified as Asian or Chinese. Lin (2019) also observed similar discourses and cited articles in which students identified as "Asian" were blamed for cheating scandals in B.C. schools. According to Anderson, these articles work to reproduce and extend the anti-Asian racism that has long been established in the Vancouver context.

What these studies demonstrate is that the ways in which categories are used matter. Seemingly neutral labels, such as "international," particularly when combined with racial categories, may be used to produce a host of negative or instrumental inferences and may mask race-based and languagebased discrimination. The use of these labels and the reproduction of these discourses are also not confined to published materials-media and policy representations are reproduced, resisted, and transformed through the daily interactions of students on Canada's campuses. For this reason, I contend that it is also necessary to examine how these categories operate locally in talk to produce particular understandings of international students. In the section that follows, drawing on the theoretical lens of language socialization (Ochs, 1996), I unpack how socially shared understandings about members of different categories can shape students' engagement in educational contexts.

\section{Categories and Language Socialization}

In her work on categories in higher education, Harklau (2000) argues the ways in which categories may be used in a given context are not neutral or random. Rather, they are shaped and limited by socially circulating discourses about who category members usually are and what they can do. In other words, "participants incorporate explicit relationship categories anticipating that recipients will draw on their understanding of the activities, motives, rights, responsibilities, and/or competences" (Pomerantz \& Mandlebaum, 2005, pp. 152-153) that are often associated with local understandings of category members. Work in the area of language socialization is useful for reflecting on how particular social values become discursively associated with different labels and the ways in which those are then taken up and reproduced in various educational spaces.

Language socialization (LS), broadly defined, is the collaborative and coconstructed process by which novice language users move toward expert status through participation in local communicative practices (Duff \& Talmy, 2011; Ochs, 1996). All participants, novices included, shape the socialization process to differing degrees, and novice and expert roles are viewed as fluid and co-constructed within and across interactions. Within an LS framework, interaction is understood to be at the heart of the socialization process. When individuals use language, they draw on their awareness of previously established cultural meanings, a process known as indexical presupposition (see, for example, Silverstein, 2003), and simultaneously create a new context from 
which such presuppositions can be drawn in the future, termed indexical entailment. In this sense, language use is understood to contribute to the reification, reproduction, and transformation of cultural systems of value, systems that are, in turn, shaped by the media and institutions with which community members interact. Therefore, from an LS perspective, the values associated with categories are not innately known to community members - rather they are acquired, reproduced, and transformed often implicitly, through interaction in the community.

In education, when the values and practices associated with particular categories conflict with students' perceptions of themselves and their goals, LS research has often observed a negative impact on those students' willingness and ability to participate in that educational community (e.g., Wortham \& Reyes, 2015; Talmy, 2009). For example, Harklau (2000) examined how the category of ESOL (English speaker of other languages) student operated differently in a high school in the United States than it did at the college level. Through an analysis of interviews with teachers and three focal ESOL students, she demonstrated how the category ESOL student came to be associated with a hardworking immigrant identity. She showed that teachers often referred to students categorized as ESOL as "kids with determination" (p. 45) and as "an inspiration for everyone" (p. 46), although they were not always represented as academically gifted. The students themselves also took up this identity, which was treated positively by others, and they reconstructed it frequently with stories of migration, hardship, and perseverance in class assignments. However, when the students arrived at college and were placed in ESOL classes, they quickly realized that ESOL students in college were not treated as having a hardworking immigrant identity. Rather, they were treated as newcomer adults who had grown up in foreign countries. As a result of the program's construction of members of the ESOL student category, the students began to resist the grammar and reading activities assigned by the teacher and became disengaged from classes. Harklau's study provides a vivid example of the ways in which implicit understandings about category members and their experiences can have very real consequences for students' engagement and understandings of themselves. For this reason, I contend that it is vital to examine the ways in which such labels operate locally in everyday talk. In the remainder of the article, I examine categorization practices related to the international student label, drawing on insights from membership categorization analysis (Sacks, 1992; Housely \& Fitzgerald, 2015).

\section{Method}

The data presented in this article come from a larger multiple case study (Surtees, 2018) that examined the peer relationships and interactions of four focal participants, Ami, Lisa, Samantha, and Blue (pseudonyms), who were participating in a 9-month English-medium program with a cohort of around 
75 students from the same home university in Japan. The four students were all 20 years old and had arrived at Pacific Western University (PWU, pseudonym) with the twin goals of improving their English and making Englishspeaking friends. The objective of the multiple case study was to explore a phenomenon, peer language socialization in study abroad, rather than to focus on the biographical particularities of any one participant. As such, it was what Stake (2000) has called an instrumental case study. The study asked the following question: How do study abroad students and their English-speaking peers describe the contribution of peer interaction and/or relationships to the focal participants' English learning?

Case studies are characterized by "boundedness or singularity, in-depth study, multiple perspectives or triangulation, particularity, contextualization, and interpretation" (Duff, 2008, p. 23). As such, case studies typically use different forms of data and perspectives to generate and discuss findings. The main data for this study consisted of audio recordings of informal conversations between the Japanese participants and their English-speaking peers and one-on-one interviews with both Japanese participants and peers (approximately $48 \mathrm{hr}$ of recorded data). These interview data, which were generated over a 4-month period in 2016 during the Japanese participants' second semester of study abroad, are the focus of the analyses presented in this article.

\section{The Research Site}

PWU is a large Western Canadian university with more than 50,000 undergraduate and graduate students, about one fifth of whom are classified as international students. ${ }^{1}$ At PWU, internationalization, international students, and English proficiency/learning were and continue to be omnipresent and somewhat sensitive topics on campus. For instance, at the time of data generation in 2016, there had been a recent protest jointly organized by domestic and international students when the government decided to raise tuition fees for international students (which were already much higher than those of domestic students). There had also been controversy in the media about a bridging program that accepted students who did not meet the mainstream English language proficiency requirements at PWU, yet which did not accept domestic students with similar levels of language proficiency. At the same time, institutional policy and student-lead initiatives were being designed to highlight the benefits of diversity and to increase the visibility of minority students. For example, a new campus magazine published in 2016 featured stories of generation 1.5 students of diverse backgrounds. At that time, nearly $25 \%$ of all student-led clubs had a specific ethnic, linguistic, racial, or cultural affiliation (e.g., Chinese $\mathrm{Club}$ ). The university also had established a wellfunded diversity initiative program. The notions of diversity, particularly linguistic diversity, were also explicitly present in the coursework completed by the focal participants in the study. In their program, all students learned 
about World Englishes, discussed issues around native-speakerism, and were introduced to critical multicultural perspectives through assignments on topics such as the Chinese head tax, Japanese internment camps, and the loss of Indigenous languages. The program had also been marketed as providing access to a multicultural community, thereby promoting diversity as a resource for students' intercultural development.

\section{Participants}

Once the focal students, Ami, Lisa, Samantha, and Blue, had joined the study, each of them was asked to recruit one or more peers at PWU who would consent to being interviewed and to having some of their informal conversations recorded. At the outset of the study, peers were defined loosely as people of similar age to the focal participants and with whom the participants interacted regularly in English (i.e., not necessarily native speakers) in informal contexts (i.e., outside the classroom). Based on these broad criteria, Ami, Lisa, Samantha, and Blue were free to recruit whichever peers they chose. All participants received two $\$ 15$ gift cards of their choice to thank them for their participation-one at the first interview and one at the final interview. Altogether, they recruited nine peers: some were roommates, others were people they met in classes, clubs, or language exchanges. Table 1 identifies peers' pseudonyms, how they met the focal student who recruited them, their institutional status, their country of origin, and the languages they spoke.

Table 1

Summary of Peer Participants

\begin{tabular}{|c|c|c|c|c|}
\hline Peer & Relationship & Institutional label & Country of origin & Languages \\
\hline So-Yi & Ami's roommate & Exchange student & Korea & $\begin{array}{l}\text { Korean (L1), } \\
\text { English (L2) }\end{array}$ \\
\hline Paulisper & Ami's classmate & Domestic student & Ontario, Canada & $\begin{array}{l}\text { English (L1), } \\
\text { Singhalese (L1), } \\
\text { Tamil (L1), } \\
\text { French (L2) }\end{array}$ \\
\hline Emma & Ami's cohortmate & Exchange student & Japan & $\begin{array}{l}\text { Japanese (L1), } \\
\text { English (L2), } \\
\text { French (L2) }\end{array}$ \\
\hline Serena & Lisa's roommate & Domestic student & $\begin{array}{l}\text { Dubai, immigrated } \\
\text { to Canada age } 10\end{array}$ & $\begin{array}{l}\text { Malayalam (L1), } \\
\text { English (L1) }\end{array}$ \\
\hline Ed & Lisa's roommate & $\begin{array}{l}\text { International } \\
\text { student }\end{array}$ & $\begin{array}{l}\text { Bangladesh/ } \\
\text { Philippines/ } \\
\text { Singapore }\end{array}$ & $\begin{array}{l}\text { English (L1), } \\
\text { Tagalog (L1), } \\
\text { Bengali (L1), } \\
\text { Spanish (L2), } \\
\text { Hindi (L2) }\end{array}$ \\
\hline Kyla & Lisa's roommate & Domestic student & $\begin{array}{l}\text { Mainland China, } \\
\text { immigrated to } \\
\text { Canada age } 8\end{array}$ & $\begin{array}{l}\text { English (L1), } \\
\text { Mandarin (L1) }\end{array}$ \\
\hline
\end{tabular}




\begin{tabular}{|c|c|c|c|c|}
\hline Peer & Relationship & Institutional label & Country of origin & Languages \\
\hline Elizabeth & $\begin{array}{l}\text { Samantha's } \\
\text { roommate }\end{array}$ & $\begin{array}{l}\text { International } \\
\text { student }\end{array}$ & United Kingdom & $\begin{array}{l}\text { English (L1), } \\
\text { Arabic (L2) }\end{array}$ \\
\hline John & $\begin{array}{l}\text { Samantha's } \\
\text { language exchange } \\
\text { partner }\end{array}$ & $\begin{array}{l}\text { International } \\
\text { student }\end{array}$ & Mainland China & $\begin{array}{l}\text { Mandarin (L1), } \\
\text { English (L2), } \\
\text { Japanese (L2) }\end{array}$ \\
\hline Bob & $\begin{array}{l}\text { Blue's language } \\
\text { exchange partner }\end{array}$ & Domestic student & $\begin{array}{l}\text { Hong Kong, } \\
\text { immigrated to } \\
\text { Canada age } 5\end{array}$ & $\begin{array}{l}\text { English (L1), } \\
\text { Cantonese (L1), } \\
\text { Japanese (L2) }\end{array}$ \\
\hline
\end{tabular}

Note. L1 = first language; $\mathrm{L} 2$ = second language.

In addition to the diverse languages and backgrounds highlighted in Table 1, in interviews, peers also described the diverse paths through which they had acquired English: some peers had learned English at home and were English-dominant (e.g., Paulisper and Elizabeth), others had learned English at school when they immigrated to an English-speaking country at a young age and used different languages at home and at school (e.g., Serena, Ed, and Kyla), and yet others had learned English through language classes in their universities abroad and were dominant in a different first language (So-Yi, John, and Emma). These peers also reported wide-ranging abilities in their additional languages. Paulisper and Elizabeth, for instance, reported having only basic knowledge of languages other than English (i.e., they were, for practical purposes, monolingual), while Kyla, Ed, Serena, and Bob reported being proficient speakers in all their languages. This wide range of experiences and expertise with different languages highlights the difficulties inherent in capturing any one student's background or experience with a single label.

\section{Analysis}

The interview data were analyzed using insights from membership categorization analysis (MCA; Housley \& Fitzgerald, 2015). MCA was first elaborated by Harvey Sacks in the 1960s in tandem with conversation analysis (for a complete collection of his lectures on this subject, see Sacks, 1992). According to Housley and Fitzgerald (2015), "MCA is not so much a method of analysis but rather a collection of observations and an analytic mentality towards observing the ways and methods people orient, invoke and negotiate social category-based knowledge when engaged in social action" (p. 6). MCA examines how categories, category resonant descriptions (Stokoe, 2012) as well as their locally associated predicates (Watson, 1978), such as activities (e.g., teach, listen) and attributes (e.g., knowledgeable, kind), are occasioned and used to perform social action in talk and text. Categorization analysis attends to "how categories are stipulated, how membership in a category is accountable and, particularly, how speakers proffer their category work as common, cultural knowledge" (Baker, 2004, p. 283). 
To accomplish this analysis, interview data were transcribed verbatim. Segments in which participants used the category "international" or "international student" were identified for further analysis. In addition, segments in which participants attributed various characteristics to participants who could conventionally be referred to as "international" (i.e., who were currently or previously categorized as "international" for institutional purposes) were identified, and they were transcribed in more detail (i.e., notation for overlap, pauses, sound stretches, and emphasis were added). Analytic memos were then developed for each segment, and each memo was reviewed and revised after each pass through the data. Once these memos had been finalized, they were examined for recurring patterns. The findings presented below provide examples of the key patterns observed across the interview data.

\section{Findings}

The first half of this section examines the ways in which the category label international was used in interview talk with the peer participants, highlighting the ways in which the use of the label generated inferences related to language deficit and racial or cultural otherness. The second half examines how participants constructed a different, more positive, category of international student that foregrounded the value of experience interacting with speakers of languages other than English.

\section{Local Constructions of the "International" Label}

In this article, I adopt the perspective that identity categories and their attendant features are used to make meaning in specific instances of talk. Antaki and Widdicombe (1998) explain that "for a person to have an identity - whether he or she is the person speaking, being spoken to, or being spoken about - is to be cast into a category with associated characteristics or features" (p. 3). These authors view categories as discursive resources that are used in situ to make social meanings and to generate inferences about people, actions, and events. For example, imagine the following hypothetical interaction:

A: I need to get my essay proofread, do you know anyone good?

B: Yes, my friend Anne can help you, she's a native speaker.

In this context, B's use of the category native speaker to describe Anne as a candidate "good" proofreader relies on shared cultural knowledge: in this case, a particular language ideology in which members of the native speaker category are endowed with the attribute of expert knowledge of English and, thus, can engage in competent proofreading. Via explicit mentions of categories, speakers are able to produce inferences in talk that allow them to 
accomplish acts such as identifying, blaming, or explaining (Jayyusi, 1984; Sacks, 1992) - or, in the case of the example above, providing a rationale, or warrant, for an assessment (i.e., of Anne as a good proofreader). To analyze how participants and I oriented to shared cultural knowledge around the category international student, I identified instances in which the category was mentioned and proceeded to examine the taken-for-granted attributes that were implied by their use in the stretch of talk immediately preceding and following the category's mention. The two examples presented below were taken from interviews with the two native English speakers that participated in the study: Elizabeth and Paulisper. As the excerpts demonstrate, the use of international in their talk served as resources for generating inferences about lower English language proficiency.

Excerpt 1 involves Elizabeth, a White English-speaking international student from the United Kingdom. At this point in the interview, I (Victoria, the interviewer) am pursuing the reason why Elizabeth agreed to participate in the study when her other roommates did not. Elizabeth's answer can, therefore, be understood as a justification of her choice. In response, Elizabeth explains that she chose to participate because she has a lot of friends who are internationals.

Excerpt 1

"A lot of my friends are all like internationals"

1 Victoria: And so what made you want to agree to do the project.

2 Elizabeth: Yeah like it sounded interesting, like quite a lot of my friends are all like

3 internationals like, kinda like um, China, Japan ... so yeah . . I just, so yeah, I

4 thought it would be interesting to kind of watch her [Samantha's] English just

5 improve.

(Elizabeth, Interview 1, 01/27/2016)

Elizabeth's response to the question in line 1 can be examined in two parts: a preface (lines 2-3), in which she explains that she has a lot of international friends, and the answer to my question (lines 3-5), in which she explains that she wants to watch Samantha's English improvement. By mentioning a specific category - internationals from China and Japan - the preface works to construct an opposition between Elizabeth, as a friend of Samantha's and a friend of internationals, and another type of friend, internationals from countries in Asia. Elizabeth's response demonstrates how the label "international" can be made to do different forms of discursive work as, from a strictly institutional perspective, she is an international student herself (Elizabeth is from the United Kingdom). However, she is an international student that speaks English as a first language, unlike Samantha, who is Japanese and learning English. Thus, in this excerpt, her mention of internationals from 
China and Japan (line 3), where English is not spoken as a first language, appears to serve as a resource for differentiating Elizabeth's position as a native speaker of English from the position of "non-English-speaking" internationals - and perhaps specifically Asian non-English-speaking internationals. In her response in lines 3 to 5, this contrast is again reproduced: Elizabeth explains that she will watch Samantha's English improve, which generates an inference that Elizabeth has both the ability as a native speaker to register Samantha's improvement and a reasonable explanation for wanting to do so-because she is a good friend to Asian international students with developing English (i.e., internationals from China and Japan).

Similarly, in Excerpt 2, Paulisper, one of Ami's peers who was a native English speaker from Central Canada, also discursively connects the category international students with language proficiency as well as country of origin (again, likely as a proxy for race although that is not made explicit). The excerpt begins as I ask Paulisper if there is anything she learned from Ami, her Japanese peer.

\section{Excerpt 2}

"Mostly my friends are from America" 
(Paulisper, Interview 1, 24/01/2016)

Initially, Paulisper replies that she has learned about "culture" from Ami (line 2). While in their recorded conversations, Ami and Paulisper did sometimes talk about "culture" in the sense of Japanese traditional holidays, the two also often discussed food, and Ami had introduced Paulisper to Korean food and had also helped her with her schoolwork. It is notable then that Paulisper produces a nonspecific reference to culture in response to my question rather than listing these other activities. I would argue that in this stretch of talk, Paulisper is reproducing discourses that position cultural difference as a resource for domestic student learning (Trilokekar, 2016).

Following this initial response, Paulisper launches into a secondary explanation in which she begins to describe, as Elizabeth did, her various relationships with other students who are also international. Also similar to Excerpt 1, these descriptions of the different challenges inherent in being friends with or communicating with "people from abroad" (lines 8-9) appear to rely upon the discursive connection between being an international student and having difficulties with English. First, in lines 4-5, she explains that she also has a roommate from China. Her use of "also" seems to indicate that Paulisper initially treats her roommate from China and Ami (a Japanese exchange student) as members of the same category - they are both Asian international students. However, Paulisper quickly revises her initial comparison by identifying what distinguishes Ami from her roommateher roommate's English is already "pretty good" because she went to an international school (line 6). Thus, Paulisper's response treats Ami as having been potentially categorizable in the same category as her roommate, a nonnative English speaker from China (i.e., an international student), but she then rejects this categorization on the grounds that her roommate's English is too advanced.

In line 7 and onward, Paulisper's account pursues this contrast, categorizing her friends and acquaintances differently based on whether or not there is a "language barrier" (line 11), explaining that it is more difficult to make friends with international students (lines 8-9) with whom there is a language barrier. Her response also discursively ties "easy" (lines 12) communication with people who speak "your native language" (lines 12-13; i.e., members 
of the native speaker category). The relevance of lower language proficiency as an accountable characteristic of the international student category is also evident in the way Paulisper takes special care to explain that Americans are only "technically" international (line 18), as there "is no language barrier there" (line 44) and "they still speak English" (line 19). Paulisper's account, thus, reproduces the ideological connection between the international student category and low language proficiency in multiple ways. An additional important aspect of Paulisper's response is that it explicitly evaluates membership in the international student category as a social disadvantage because category membership is discursively tied to a troublesome language barrier that apparently impedes members' capacities for forming friendships. Her explanations, thus, draw on and reproduce the "difference as deficit" perspective described by Guo and Jamal (2007).

While Paulisper's description of international students draws on socially shared understandings of the "language barriers" that such students might face, it is also worth considering the social action that is being accomplished by her discursive work in this excerpt. Indeed, the apparent reason for her lengthy explanation does not come until the very end of the excerpt in lines 23 to 24, where Paulisper explains that perhaps her friendship with Ami, as a member of the international student category, will allow her to expand her friendship circle, which currently consists mostly of Americans. In other words, Paulisper's extensive categorization practices serve as an additional explanation for why Ami is a potentially valuable friend - because by pushing through the language barrier with Ami, Paulisper may learn how to "reach out" (line 22) and make friends with more international students. Her extensive explanations and difficulties producing this response (i.e., the many reformulations and hesitations) also suggest that her professed intention to make more international friends is not the norm for most members of the native speaker category (like her), who generally prefer "easy communication" (see lines 12-13). By referring to the extra experience that she is required to have in order to interact "easily" with international students, Paulisper's response alludes indirectly to the notion that interaction is a jointly constructed and negotiated process in which all parties must mobilize various strategies and previous knowledge. Here, Paulisper also seems to be acknowledging that the knowledge and experience necessary to interact with international students is not inherent to members of the native speaker category but rather is a learned skill acquired through interactions with people who speak diverse Englishes. In the section that follows, I examine other instances in which participants explicitly described the ability to interact easily with diverse English speakers as a learned behaviour, often acquired through experience abroad, or in some cases through their own language learning histories. 


\section{Contributions of Mobile and Multilingual Students}

Identifying and analyzing explicit mentions of categories, such as the mention of the international students in the excerpts above, is only one way to investigate categories in talk. According to Pomerantz and Mandlebaum (2005), to investigate categorization processes more broadly, the analyst must also examine how speakers engage in sense-making through discursively configuring attributes, characteristics, knowledge, or actions that can evoke membership in different social categories. Attention must also be paid to how speakers claim, attribute, and resist inclusion in those categories (Day, 1998). In the interview data collected for this study, a number of category characteristics were routinely mentioned as resources for describing peers that were particularly helpful to or appreciated by the Japanese students. I argue that the regularity with which these characteristics were used as resources for meaning-making in interviews suggests that they form the basis of a locally relevant social category that foregrounds the positive attributes of students that fall into the institutional category of "international" or the socially constructed category of "diverse" students. In what follows, I present two excerpts as examples - one from a Japanese participant, Samantha, and one from an international student from Singapore, Ed.

Excerpt 3 involves one of the focal Japanese students, Samantha. At this point in the interview, I am asking Samantha to talk about situations in which she likes to speak English. She responds by citing a number of characteristics and behaviours of peers who succeed in making communication more comfortable for her.

\section{Excerpt 3}

"They accept me to speak"

\begin{tabular}{|c|c|c|}
\hline 1 & Victoria: & So what kinds of situations do you like speaking English the best. \\
\hline 2 & Samantha: & $\mathrm{Mm} \ldots$. . ah ... I think that I realize is ah people who knows that, $\mathrm{mm}$ \\
\hline 3 & & non-native speakers? they can- they- I think, ah ... \\
\hline 4 & & they accept me like not good [laugh] I'm not good at speaking English but they \\
\hline 5 & & accept me to speak and they hear me more like $\mathrm{mm}$ \\
\hline 6 & & kindly like, I don't know how to say but, the $\mathrm{mm}$... \\
\hline 7 & & some people doesn't use- doesn't get used to the non-native speakers \\
\hline 8 & & English? So they I think that they ... they also $\mathrm{mm}$ had to hear the- hear non- \\
\hline 9 & & native speakers' English? so I think $\mathrm{mm}$... \\
\hline 10 & & yeah it's so depressing and I think... \\
\hline 11 & & To speak with Elizabeth is so comfortable? and I also speak with you is so co- \\
\hline 12 & & (Samantha, Interview 1, 1/29/2016) \\
\hline
\end{tabular}

After a long hesitation and several stretched fillers (line 2), Samantha responds to my question not by describing a situation but rather by describ- 
ing a category of people with whom she likes to speak English: "people who knows the non-native speakers" (lines 2-3). She then goes on to explain that people who fall into this category display certain behaviours including accepting her English despite her difficulties (lines 4-5) and hearing her "kindly" (line 6). The remainder of her response, lines 7 to 12, serves to justify her claim that the category of people she has just constructed is a legitimate social category that is relevant for answering my question at line 1 . The evidence presented to warrant her claim is that, according to Samantha, "some people" (line 7) are not used to non-native speakers, an experience that she evaluates as "depressing" (line 10). In contrast, she states that communication with other people who belong to the "used to non-native speakers" category, such as Elizabeth (her roommate from the United Kingdom) and myself, a Canadian English speaker, are "so comfortable" (line 11). Through these evaluations, Samantha's account constructs contrasting moral versions of peers at PWU in terms of their familiarity with non-native speech and their willingness to accept it.

A crucial aspect of this excerpt is the way in which the mentions of native/ non-native categories are used to accomplish categorization. By explicitly mentioning acceptance of non-native speakers, Samantha's response makes relevant her own membership in the non-native speaker category. Her membership is further reinforced through her mentions of behaviours associated with that category, such as when she explains that "I'm not good at speaking English" (line 4) and she produces hesitations and explicit unknowing stances (e.g., "I don't know how to say," line 6). What is interesting about Samantha's mention of non-native speakers is that it also makes the contrasting category, native speaker, potentially available as a resource for categorization in this context. Both Elizabeth and I, whom she mentions as examples of the "used to non-native speakers" category at the end of the excerpt, are native speakers in the conventional sense (me of Canadian English and Elizabeth of British English). However, while the native speaker category may have some relevance here, Samantha's account makes it clear that native speaker status is not the main criteria for inclusion in this category. Rather, two alternative characteristics, being used to non-native English and kindly accepting of non-native English, are constructed as the category's defining attributes. ${ }^{2}$

The notion of being "used to" the English of learners was a recurring theme throughout the interviews. In Excerpt 2, Paulisper alluded to it as a type of experience that was desirable but difficult to acquire for native speakers. In Excerpt 4 below, Ed, Lisa's roommate from Singapore, also mentions her experience listening to different Englishes as a resource that allows her to communicate effectively with English learners. In this excerpt, I have just asked Ed about any challenges she faces when talking to Lisa, her Japanese roommate. 
Excerpt 4

"Maybe cause l'm used to it"

\begin{tabular}{lll}
\hline 1 & Victoria: & Is there any challenge when you're talking to ah Lisa? \\
2 & Ed: & Lisa? No, it's just like some- like I don- maybe because I'm used to it? \\
3 & & Cause l've had a lot of friends whose visited? Who, not like tour visited but who \\
4 & came to . . Bangladesh or Singapore just to learn English? And um, when they \\
5 & did it sort of I sort of, I don't know, I got used to the way they're talking so, \\
6 & whenever I talk to Lisa it's sort of the same?
\end{tabular}

(Ed, Interview 1, 01/21/2016)

In answering this question in line 2, Ed does not hesitate-she immediately replies that she does not have challenges speaking to Lisa. She then provides a rationale for why this might be the case: she is used to it from her experiences with friends who came to learn English in Singapore and Bangladesh. Thus, once again, in this excerpt, there is evidence to suggest that participants recognized experience with other international students as a resource for reducing communication difficulties. According to Ed, speaking English with Lisa is similar to speaking English with them. By explicitly mentioning that her friends came to Singapore to learn English, Ed's answer serves to reference her friends' lower English proficiency and by subsequently equating her interactions with those friends to her interactions with Lisa, Ed's description also collects Lisa in that same learner category. Ed's response also does other important interactional work: By being dismissive of the potential challenges involved in interacting with Lisa, Ed also displays "being accepting," a characteristic that was associated with the category of peer that Samantha constructed in Excerpt 3.

In addition to the responses analyzed above, in which categorization practices were particularly evident, the Japanese study abroad participants also recounted a number of stories that reproduced contrasts between helpful and less helpful peers. These stories tended to reproduce similar contrast between peers, usually White native English speakers, who were lacking patience, or were rude or disrespectful, and other peers, usually international or generation 1.5 students who took time to guide the Japanese students when they were experiencing cultural and linguistic difficulties.

For example, Ami explained that with her British roommate, she often had to ask her to slow down or explain words and that her roommate sometimes appeared visibly annoyed and refused to take the time to explain. Ami described her first encounter with her British roommate as follows:

She speaks British English so, so fast and I couldn't understand at all the first day. It was my first day to come here and I lose my confident, I thought I can understand English a little bit but I came 
here and I couldn't understand what she is saying to me and I feel really like negative? So, from first day, I lose hope. (Ami, interview 1 , 4/01/2016)

Conversely, she described her interactions with a Taiwanese student that she met during her homestay on winter break as a particularly important resource for her English development:

She's from Taiwan and she helps me a lot, so I talked a lot to her and yeah, she helps me, support me about English or how to contact with communicate with the homestay family.... Cause she have experience to homestaying for half a year so she's kind of expert, so especially I asked her a lot about English and she helps me to speak English fluently. (Ami, interview 1, 4/01/2016).

Lisa, Samantha, and Blue all told similar stories in which a multilingual peer with experience living and studying in another country took the time to explain linguistic or cultural conventions. In both Samantha and Lisa's case, it was a Korean roommate who helped them understand dormitory life and took time to listen while they were in the early stages of their study abroad sojourns. In Blue's case, it was Bob, a Chinese-born Canadian who had previously lived in Japan, that introduced Blue to his group of friends to support Blue's development of an English social network.

\section{Discussion}

The findings presented in this article showed how participants, all undergraduates at a large Canadian university, constructed two different categories related to diverse students in their interviews - the international student category and the "used to non-native speakers" category. In the first section of the findings, through a close analysis of interview excerpts, I demonstrated how the international label was used to indirectly reference students' English language deficits and racial or cultural otherness. In the second section, an alternative and less well-defined category of university peer was exploredpeers who are "used to" learner English. In the sections that follow, I consider some of the implications of these findings for thinking about representations of international students in higher education.

\section{The Value of Deconstructing Category Labels}

When a category is clearly named, and particularly when it is institutionally relevant like the international student category, it is an indication that the category holds cultural relevance in the community in which it is used and that criteria for claiming membership within those categories are often shared to some extent across that community (Jayyusi, 1984). That this was the case at PWU is evident across the dataset from the ways in which this and similar 
labels (e.g., exchange students) were readily recognized by the participants and myself, the interviewer, as referring to language ability and racial otherness, even when language ability and race were referenced only indirectly (e.g., through reference to barriers or country of origin).

This finding does not imply that at PWU, international students are necessarily openly treated with hostility as "problems" or as deficient. As the excerpts involving Paulisper and Elizabeth demonstrated, while the participants in this study used the label to refer to otherness and difficulty, they did not produce explicitly negative judgements of international students, such as the ones that Lin (2019) observed in her analysis of comments in the Canadian media. However, the fact that these students can and did use the category of international student to represent certain deficit perspectives points to a pervasive institutionalized representation of international students as necessarily having difficulties that must be overcome. The analyses demonstrated how students also reproduced the discursive connection between the international student category and "being Asian" that both Lin (2019) and Anderson (2019) observed in their work.

As work in language socialization has shown, these types of representations constructed through day-to-day interactions are likely to have consequences for the ways that students are treated, as well as the ways that those students engage with others and with their coursework at the university. Such category constructions are, thus, in some ways especially harmful because they may hide beneath the guise of neutrality and are less likely to be discussed openly within institutions. I agree with Anderson (2019) who proposes that educators can address this issue by providing students with tools for critically analyzing media representations. Lippi-Green (1997) offers some excellent ideas and tools for engaging with films and other media. Additional principles of media literacy education can be found on Canada's Media Smarts site: http://mediasmarts.ca/digital-media-literacy/general-information/digital-media-literacy-fundamentals/media-literacy-fundamentals.

\section{Being "Used to" Speakers of Diverse Englishes}

The local construction of the international category in these data stood in stark contrast to an alternative and less well-defined category of university peer-multilingual and mobile peers who are "used to" learner English. This category of peer was constructed in contrast to peers who had little desire, patience, or ability to interact with newcomers and learners of English (often monolingual native speakers of English). This finding is not new-in her research in English medium universities in Europe, Kalocsai (2009) also found that Erasmus students described English native speakers "as uncaring and inefficient communicators" (p. 40), and, instead, preferred the mutual support they received from other multilingual students. In the Canadian context, Surtees and Balyasnikova (2016) similarly recounted the case of an 
international graduate student from Mongolia, Dianne, who explicitly sought out people who "had been abroad and know the struggles with a foreign language" (p. 71). The category contrasts constructed in these participants' interviews, as well as in Kalocsai's and Surtees and Balyasnikova's research, appear to rely primarily on members' experience or lack of experience with international others, their ability to listen to and understand different types of English, and their willingness to accept others. While in Kalocsai's study, students excluded native speakers from the category of helpful and efficient communicators, in this research, the local construction of this category did not necessarily exclude native speakers of English, as both Elizabeth and I were categorized as accepting peers. Rather, the participants' descriptions of helpful peers emphasized and celebrated their ongoing meaningful engagement with students from diverse backgrounds and pointed to their keen listening skills and patience. I propose that the attributes of this alternative category of helpful peer may be profitably understood through the conceptual lens of language brokers (Lillis \& Curry, 2006), which I describe in the next section.

\section{Language Brokers}

In the sociology literature, brokerage is defined as "the process of connecting actors in systems of social, economic, or political relations in order to facilitate access to valued resources" (Stovel \& Shaw, 2012, p. 141). Lillis and Curry (2006), who examine brokering in academic literacy, conceptualize brokering as mediation where brokers "are involved in helping people interact with written texts" (p. 12). Wenger (1998) also identifies brokers as those who have "multimembership" (p. 109) and who can, by virtue of their knowledge of more than one community, bridge gaps for peripheral participants. In each story, the Japanese students named at least one broker who was able and willing to facilitate interaction with other English speakers. In each case, these peers spoke English more expertly than the Japanese students but were not native speakers and had not grown up in Canada. In this sense, they were not only relative experts in English but also had more expertise in navigating mobility experiences. In other words, these peers appeared to have developed the multimembership described by Wenger and were, thus, able to recognize the language struggles of the Japanese participants and to provide appropriate support. ${ }^{3}$ I propose that the concept of brokers rightly emphasizes the concrete ways in which international students contribute to campus communities through an emphasis on their ability to interpret newcomers' language use and bridge the gaps between their own perspectives and the perspectives of others. Further research could expand on this notion and explore the ways in which students with international and multilingual experiences engage in a wide range of brokering activities on Canadian campuses. 


\section{Conclusion}

It is my hope that the analyses presented within this article have demonstrated how seemingly neutral educational categories can and do operate in everyday talk to reproduce deficit understandings of students. I also hope that it has encouraged readers to reflect critically on the ways in which institutional labels operate within their own institutions. As Coleman (2015) explains in his work on campus internationalization, in an age of global migrations, each student possesses increasingly diverse and overlapping linguistic repertoires. If professionals in higher education are to truly embrace the diversity of linguistic and cultural repertoires that international students bring to Canadian campuses, we must first confront and deconstruct socially circulating assumptions about what students lack and begin to shift our focus to what students can do with the languages they use.

\section{Notes}

1. I have avoided providing a source or exact statistic to maintain anonymity. The information about Pacific Western University (PWU) was gathered through publicly available sources such as the university website.

2. Here, it is worth mentioning that in the Japanese participants' coursework, they were often asked to reflect critically on the label "native speaker" and that this may have also contributed to Samantha's avoidance of the term.

3. In most cases, the peers with whom the Japanese students connected were of Asian ethnicity, pointing to the potential relevance of a "pan-Asian, transnational, multilingual" community (Duff, 2010, p. 182). Indeed, Samantha specifically referenced the Asian ethnicities of her dance club members and how that shared background contributed to their ability to communicate easily with each other.

\section{Acknowledgement}

I would first like to express my gratitude to the two anonymous reviewers who provided insightful comments on earlier drafts and to the editors who encouraged me to submit this manuscript. I would also like to thank my PhD dissertation committee members, Dr. Patsy Duff, Dr. Steven Talmy, and Dr. Zappa-Hollman, who guided me through the research and analysis process. This research was made possible by the funding and support of the Social Sciences and Humanities Research Council.

\section{The Author}

Victoria Surtees is a lecturer in the Department of Language and Literacy Education at the University of British Columbia. Her research focuses on the experiences and language use of international and study abroad students. 


\section{References}

Anderson, T. (2019). News media representations of international and refugee postsecondary students. Journal of Higher Education. Advanced online publication. http://doi.org/10.1080/0 0221546.2019.1587977

Baker, C. D. (2004). Membership categorization and interview accounts. In D. Silverman (Ed.), Qualitative research: Theory, methods and practice (2nd ed., pp. 162-176). London: Sage.

Coleman, J. A. (2015). Social circles during residence abroad: What students do, and who with. In R. Mitchell, N. Tracy-Venture, \& K. McManus (Eds.), Social interaction, identity and language learning during residence abroad (pp. 33-51). European Second Language Association. Retrieved from http://www.eurosla.org/eurosla-monograph-series-2/

Deschambault, R. (2015). Economizing education: Fee paying ESL students in a public high school (Unpublished doctoral dissertation). University of British Columbia, Vancouver, Canada.

Duff, P. A. (2008). Case study in applied linguistics. New York: Taylor \& Francis Group.

Duff, P. A. (2010). Language socialization into academic discourse communities. Annual Review of Applied Linguistics, 30, 169-192. http://doi.org/10.1017/S0267190510000048

Duff, P. A., \& Talmy, S. (2011). Language socialization approaches to second language acquisition. In D. Atkinson (Ed.), Alternative approaches to second language acquisition (pp. 95-116). New York: Routledge. http://doi.org/10.4324/9780203830932

Findlay, S., \& Köhler, N. (2010, November 10). The enrollment controversy: Worries that efforts in the US to limit enrollment of Asian students in top universities may migrate to Canada. Maclean's. Retrieved from http://www2.macleans.ca/2010/11/10/too-asian/

Government of Canada. (2014). Canada's international education strategy. Retrieved from http:// international.gc.ca/global-markets-marches-mondiaux/education/strategy-strategie. aspx?lang=eng

Guo, S., \& Jamal, Z. (2007). Nurturing cultural diversity in higher education: Critical review of selected models. Canadian Journal of Higher Education, 37(3), 27-49.

Harklau, L. (2000). From the "good kids" to the "worst": Representations of English language learners across educational settings. TESOL Quarterly, 34(1), 35-67. http://doi. org/10.2307/3588096

Housley, W., \& Fitzgerald, R. (Eds.). (2015). Advances in membership categorisation analysis. London: Sage.

Jayyusi, L. (1984). Categorization and the moral order. London: Routledge.

Kalocsai, K. (2009). Erasmus exchange students: A behind-the-scenes view into an ELF community of practice. Apples-Journal of Applied Language Studies, 3(1), 25-49.

Lillis, T., \& Curry, M. J. (2006). Professional academic writing by multilingual scholars: Interactions with literacy brokers in the production of English-medium texts. Written Communication, 23(1), 3-35. http://doi.org/10.1177/0741088305283754

Lin, G. (2019). Decolonizing the social imaginaries of British Columbia's international education phenomenon (Unpublished doctoral dissertation). University of British Columbia, Vancouver, Canada.

Lippi-Green, R. (1997). English with an accent: Language, ideology, and discrimination in the United States. New York: Routledge.

Macdonald, M. (2019, May 6). International student enrolment continues to soar in Canada. University Affairs. Retrieved from https://www.universityaffairs.ca/news/news-article/international-student-enrolment-continues-to-soar-in-canada/

Marshall, P. (2002). Cultural diversity in our schools. Belmont, CA: Wadsworth/Thomson.

Ochs, E. (1996). Linguistic resources for socializing humanity. In J. J. Gumperz \& S. C. Levinson (Eds.), Rethinking linguistic relativity (pp. 407-437). New York: Cambridge University Press.

Ochs, E., \& Schieffelin, B. B. (2012). The theory of language socialization. In Handbook of language socialization (pp. 1-21). Malden, MA: Blackwell. 
Paltridge, T., Mayson, S., \& Schapper, J. (2014). Welcome and exclusion: An analysis of The Australian newspaper's coverage of international students. Higher Education, 68, 103-116. http://doi.org/10.1007/s10734-013-9689-6

Pomerantz, A., \& Heritage, J. (2013). Preference. In J. Sidnell \& T. Stivers (Eds.), Handbook of conversation analysis (pp. 210-228). Chichester: Wiley-Blackwell.

Pomerantz, A., \& Mandlebaum, J. (2005). Conversation analytic approach to the relevance and uses of relationship categories in interaction. In K. L. Fitch \& R. E. Sanders (Eds.), Handbook of language and social interaction (pp. 149-171). Mahwah, NJ: Lawrence Erlbaum Associates.

Quinn, S. (2012, June 1). Why do so many Canadians see ethnic enclaves as a threat? The Globe and Mail. Retrieved from http://www.theglobeandmail.com/news/british-columbia/why-doso-many-canadians-see-ethnic-enclaves-as-a-threat/article4226087/

Robertson, S. (2011). Cash cows, backdoor migrants, or activist citizens? International students, citizenship, and rights in Australia. Ethnic and Racial Studies, 34(12), 2192-2211. http://doi. org/10.1080/01419870.2011.558590

Sacks, H. (1992). Lectures on Conversation, Volume I, II. (G. Jefferson, Ed.). Oxford, UK: Blackwell. http://doi.org/10.1002/9781444328301

Silverstein, M. (2003). Indexical order and the dialectics of sociolinguistic life. Language and Communication, 23, 193-229. http://doi.org/10.1016/S0271-5309(03)00013-2

Smith, D. G. (2015). Diversity's promise for higher education: Making it work. Baltimore: Johns Hopkins University Press. http://doi.org/10.1353/csd.2010.0004

Stake, R. E. (2000). Case Studies. In N. Denzin \& Y. Lincoln (Eds.), Handbook of Qualitative Research (pp. 435-454). London: Sage Publications. https://doi.org/10.1258/096214400320575624

Statistics Canada (2019). Postsecondary enrolments, by registration status, institution type, status of student in Canada and sex [Table 37-10-0018-01]. Retrieved from https://www150.statcan. gc.ca/t1/tbl1/en/tv.action?pid=3710001801

Stokoe, E. (2012). Moving forward with membership categorization analysis: Methods for systematic analysis. Discourse Studies, 14(3), 277-303. http://doi.org/10.1177/1461445612441534

Stovel, K., \& Shaw, L. (2012). Brokerage. Annual Review of Sociology, 38, 139-158.

Surtees, V. (2018). Peer language socialization in an internationalized study abroad context: Norms for talking about language (Unpublished doctoral dissertation). University of British Columbia, Vancouver, Canada.

Surtees, V., \& Balyasnikova, N. (2016). Culture clubs in Canadian higher education: Examining membership diversity. Canadian Journal for New Scholars in Education, 7(1), 66-73.

Talmy, S. (2009). Resisting ESL: Categories and sequence in a critically "motivated" analysis of classroom interaction. In H. Nguyen \& G. Kasper (Eds.), Talk-in-interaction: Multilingual perspectives (pp. 181-213). Honolulu. HI: University of Hawai'i, National Foreign Language Resource Center.

Trilokekar, R. D. (2016). Orientalism alive and well: Canadian policy discourse on international student mobility. Paper presented at Green College, Vancouver, Canada.

Wenger, E. (1998). Communities of practice: Learning, meaning, and identity. Cambridge: Cambridge University Press.

Wortham, S. E. F. (2005). Socialization beyond the speech event. Journal of Linguistic Anthropology, 15(1), 95-112. http://doi.org/10.1525/jlin.2005.15.1.95 